Article

\title{
Environmentally Friendly Business Practices among Low-Income Households in Rural Peninsular Malaysia
}

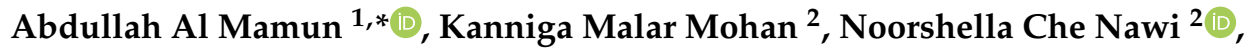 \\ Muhammad Mehedi Masud ${ }^{3}$, Rajennd Muniady ${ }^{4}$ and Noor Raihani Zainol ${ }^{2}$ \\ 1 UCSI Graduate Business School, Faculty of Business and Management, UCSI University, Cheras, \\ Kuala Lumpur 56000, Malaysia \\ 2 Faculty of Entrepreneurship and Business, Universiti Malaysia Kelantan, Kota Bharu 16100, Malaysia; \\ kani.umk.edu@gmail.com (K.M.M.); norshella@umk.edu.my (N.C.N.); raihani@umk.edu.my (N.R.Z.) \\ 3 Faculty of Economics and Administration, University of Malaya, Kuala Lumpur 50603, Malaysia; \\ mehedi@um.edu.my \\ 4 Department of Business Studies, New Era University College, Kajang 43000, Malaysia; \\ rajennd.m@newera.edu.my \\ * Correspondence: abdullaham@ucsiuniversity.edu.my or mamun7793@gmail.com; Tel.: +60-133003630
}

Received: 7 August 2020; Accepted: 4 September 2020; Published: 7 September 2020

\begin{abstract}
The purpose of the study is to predict the intention and behavior towards environmentally friendly businesses (EFB) among low-income families in rural Peninsular Malaysia within the framework of the theory of planned behavior (TPB). Data were collected from 420 low-income household heads through structured interviews. The results reveal a significant impact of environmental concern (EC) and eco-literacy (EL) on the attitude towards the environment (ATE); normative belief (NB) and motivation (MO) on subjective norms (SUN); and skills and knowledge (SK) on perceived behavioral control (PBC). Additionally, there was a positive and statistically significant effect of ATE, SUN, and PBC on the intention towards environmentally friendly business (ITEFB) and the ITEFB on environmentally friendly business adoption behavior (EFBAB). This study provides empirical evidence with a proposed research model to address the environmental issues through improving the socioeconomic condition of low-earner families. The Malaysian government and relevant agencies should focus on improving EL, EC, MO towards EFB, and the SK regarding EFB among the low-income households.
\end{abstract}

Keywords: green business; low-income households; rural areas; theory of planned behavior; Malaysia

\section{Introduction}

The poverty level and inequality in income distribution in Malaysia have been ignored due to rapid economic growth, and the reduction of overall inequality has not been pursued and monitored as a main objective of the national politics [1]. For national poverty statistics, research carried out by Abdullah [2], who used three measures of the poverty lines, noted that the official income of the poverty line is too low, which underestimates the extent of poverty in Malaysia. Lee and Khalid [1] highlighted that there is a rising trend in the inequality of earning in both the private and public sectors in Malaysia despite the rapid economic growth. Saari, Dietzenbacher, and Los [3] reported the increase of inequality in the distribution of income across rural and urban areas, as well as skilled and unskilled workers in Malaysia. Recently, the focus has been on the poorest $40 \%$ of the population, as enhancement in the household's living standards in this segment has lagged behind in addressing inequality in income distribution. It is therefore crucial to examine the income generating alternatives for the low-income rural households in Malaysia, which is in line with the government's recent initiatives to reduce poverty and improve the income of low-income households. 
The rapid economic growth in Malaysia is accompanied by social inequality and environmental degradation [4]. Moreover, climate change is widely considered as the leading threatening environmental problem [5]. There are many climatic environmental problems, such as global warming, changes of climatic pattern, environmental degradation, ozone depletion, ecosystem imbalance, and ecological problems, which are prevalent in the scientific literature [6,7]. Scientists are extensively looking for the best options to minimize the impacts [8]. The public awareness, knowledge, perception, attitudes, adaptation behavior, and other individual engagements are empowered in the research community to provide an alternative option to lessen the threatening environmental problems $[8,9]$. The behavioral responses to the effects of climate change and good understanding of environmental issues can lessen the influence of individual action in reducing the climate change conditions [10]. The rural communities could benefit by adopting green economic activities that can address environmental and socio-economic issues. Eco friendly business (EFB) can generate sustainable development through sustainable income [11].

The EFBs improve the life quality of customers, employees, the communities in which they operate, and the environment through the adoption of principles, policies, and practices [12]. To minimize the adverse effects of climate change and to protect the environment, EFB practices are commenced among entrepreneurs. EFB practices can be implemented from the production of environmentally friendly products as well as green processes of entire economic activities [12]. However, not all EFBs are suitable for low-income households, because they need to be introduced to viable and low-cost EFBs such as bee-keeping, foresting, community foresting, nurseries, solar panel installation and repair, and green composting. For the green entrepreneurs, it starts with identifying the EFB idea, followed by setting up the EFB and creating green value chains and green marketing. It is about adopting the most updated environmentally friendly products and process to produce the goods (green products and processes) and services (green services) in a sustainable way. Thus, this study can fill the gaps through the development of high economy standards to solve the problems of the environment. These factors contribute to the tightening of international and national environmental standards, as well as increasing the production of competitive products in the marketplace [13].

The earlier studies of green initiatives commonly concentrated on three crucial areas: (1) green supply chain [14,15], (2) green purchasing [16-20], and (3) green vehicles [21-24]. Therefore, this research intended to investigate the determinants that affect the intention and behavior of poor families in the rural area of Malaysia. This study highlights the current research gaps, as the use of the theory of planned behavior (TPB) has been adapted to a very limited extent in the context of low-income households. In this regard, this study integrates theoretical assumptions from the literature review with empirical evidence that contributes towards environmentally friendly business practices.

\section{Literature Review}

In understanding the link between the intention and behavior towards environmentally friendly business (EFB) within the framework of the theory of planned behavior (TPB), it is important to explain the review of the literature as below.

\subsection{Theory of Planned Behavior (TPB)}

The TPB by Ajzen [25] is the most adopted theory to explore the attitude-behavior relation. TPB has five dimensions that clarify human intention and behavior, including attitudes towards behavior, subjective norms, perceived behavioral control, intention, and behavior [25]. Numerous earlier studies have adopted TPB to examine the intention towards environmentally friendly consumption [16-18]. Apart from the dimensions proposed in TPB, previous studies have adopted a wide range of variables supported by empirical findings, such as environmental value [26], environmental awareness [21,27], social preferences for environmental quality [22], and convenience [28]. The next section presents the details of selected indicators and findings of earlier studies. 


\subsection{Attitude towards the Environment (ATE)}

An individual's ATE is the evaluative response that reflects that person's beliefs about their behavior. The two key components of attitude are as follows: (a) the beliefs about the consequences of performing a specific behavior, and (b) the corresponding judgments about the potential consequences of such behavior [25]. To some extent, pro-environmental behavior reflects the sacrifice of self-interest for collective benefits; therefore, the corresponding judgments about the potential consequences of such behavior might not be favorable. Several studies have examined the ATE and the intention regarding energy conservation [29], willingness to pay higher prices for environmentally friendly products [30], and green vehicles [24]. Earlier studies also reported the positive effect of ATE on the intention towards environmentally friendly products $[24,26]$. Under the premises of TPB and the findings of earlier studies, this study formulated the following hypothesis:

Hypothesis (H1). ATE has a positive effect on intention towards environmentally friendly business (ITEFB).

\subsection{Factors Affecting ATE}

Earlier studies revealed that the ATE is affected by self-efficacy, environmental concern (EC), and eco-literacy (EL) [31-33]. However, this study only selected EC and EL. This is because self-efficacy has been studied as a component of motivation, which is related to performance [34], and it is linked to a person's belief about their capabilities to perform a task [35]. Thus, self-efficacy is believed to be able to explain the changes in PBC rather than the ATE of a person.

\subsubsection{Environmental Concern (EC)}

Environmental consideration is embedded in one's mind, and EC refers to the perceptions of oneself as a part of a natural environment [36]. EC has recently gained the interest of the community. Nowadays, consumers are interested in ecological or green products, due to their positive perception of healthier options in sustaining the environment for the upcoming generation. People are willing to change their brand selection for ecological purposes, which can reduce the damage towards the environment by avoiding pollution [37].

EC is the key determinant of ATE, and it is linked with the consciousness of negative impacts on nature [38,39]. It is recommended that EC is associated with a person's basic beliefs [30,40]. Prior research indicated that EC is linked to eco-friendly behavior such as buying harmless items, recycling, and donating funds to the agencies working towards environmental sustainability [38,41]. EC could also indirectly influence behavior [42]. An earlier study confirmed that EC has a direct influence on attitudes towards environmentally friendly items [43]. EC can directly influence the attitude towards green hotels [44]. Cabuk, Tanrikulu, and Gelibolu [45] and Chen [46] concluded that EC is the main contributor to the users' attitude towards organic food. As the current environmental conditions are deteriorating and present severe issues, the issue must be addressed through eco-friendly behavior by ecologically concerned consumers. EC is an important factor to examine the ATE of the rural people's intention and behavior towards EFB. In line with the previous studies, this study hypothesizes the following:

Hypothesis (H2). EC has a positive effect on ATE.

\subsubsection{Eco-Literacy (EL)}

EL refers to the knowledge of facts and relationships that affect the environment. The in-depth knowledge of environmental issues and their effects on nature could change the people's ATE. Studies highlighted that knowledge of environmental issues can positively influence consumer intention and actual buying behavior of eco-friendly products $[47,48]$. Knowledge of organic food can positively affect the creation of ATE [49]. Previous research proposed that EL can moderate the relationship between ecological attitude and green behavior, and it clarified the effect of EL on consumer ecological 
behavior [37]. People's knowledge about the environment could encourage the adoption of green behavior and becoming involved in eco-friendly business. The following hypothesis is predicted:

Hypothesis (H3). EL has a positive effect on ATE.

\subsection{Mediating Effect of ATE}

Previous studies found that EC, EL, ATE, and ITEFB are connected. EC and EL have significant positive effect on the ATE [31-33]. Similar studies found that ATE has a positive effect on intention based on the tested relationship between EC, EL, and ATE and ATE with intention. Therefore, this paper intends to measure the mediating effects of ATE between EC, EL, and ITEFB. Thus, the following hypotheses are suggested:

Hypothesis (H4). The ATE can mediate the effect of EC on the ITEFB.

Hypothesis (H5). The ATE can mediate the effect of EL on the ITEFB.

\subsection{Subjective Norms (SUN)}

SUN signify the apparent public tension to reacting to the external opinions that influence a person's action [24]. Rivis and Sheeran [50] indicated that the SUN are the way people's desired behavior is determined by their beliefs. Ridha \& Wahyu [51] found that SUN were more predictive of the intentions to perform normative behaviors. In this regard, SUN are considered to be an individual's perceptions about the social force imposed by people who are important to perform or not perform certain behaviors [52]. It can be described as others' views and thoughts on the proposed behavior. These perceptions play a crucial role, and they could pressure someone to perform a particular behavior such as adopting EFB. SUN are an individual's perception about what the closest people think (e.g., family, friends, colleagues, and relatives) about their behavioral performance $[51,53,54]$. Earlier studies reported on the positive effect of SUN on the intention towards environmentally friendly products $[17,24,55,56]$. Under the premises of TPB and findings of earlier studies, the second hypothesis is created:

Hypothesis (H6). SUN has a positive effect on ITEFB.

\subsection{Factors Affecting SUN}

Previous studies found that normative beliefs (NBs) [57,58] and motivation (MO) to comply [58] can affect the SUN. NBs are the perception of what others want the person to perform, and the MO to comply is based on the person's perceptions. This study operationalized SUN as perceived social pressure to conduct a behavior; NB and MO to comply were selected.

\subsubsection{Normative Belief (NB)}

NB refers to the belief that others think or assume that a person should decide whether to perform or not for the targeted behavior [59]. NBs can be defined as someone who believes that the most significant people will evaluate their behaviors. This evaluation will help them to identify their advantage and disadvantage so that they can improve their behaviors. The rationale for the effects of NBs is that an individual may decide to involve themselves in a specific behavior, although it is initially not good or favorable to them [60]. Under the premises of TPB, the following hypothesis is suggested:

Hypothesis (H7). NB has a positive effect on SUN. 


\subsubsection{Motivation (MO)}

MO refers to an individual's MO to comply with society [59]. An individual who thinks that he or she should perform a behavior will be aware of the social pressure [30,61]. It is believed that a person will sense or undergo social pressure to execute a behavior to obtain the approval of people who are important to him or her. The MO by the family, friends, and relatives could encourage an individual to adopt EFB. Under the premises of TPB, the following hypothesis is predicted:

Hypothesis (H8). MO has a positive effect on SUN.

\subsection{Mediating Effect of SUN}

Previous studies found NB and MO to have a significant positive effect on intention [58]. Several studies [32,62] found that SUN can affect the intention. This study intended to measure the mediating effect of SUN between NBs, MO, and ITEFB. Thus, the following hypotheses are suggested:

Hypothesis (H9). SUN can mediate the effect of NB on the ITEFB.

Hypothesis (H10). SUN can mediate the effect of MO on the ITEFB.

\subsection{Perceived Behavioral Control (PBC)}

Individuals may have a positive attitude towards a behavior and positive subjective norm, but the TPB theorized that a person also needs perceived control to perform a behavior. PBC refers to an individual's perception towards his or her abilities and the sense of control over a situation [25]. The performance of the behaviors, to some extent, depends on the availability of necessary opportunities and resources [25,63], which represent an individual's actual control over a specific behavior. Therefore, PBC could be influenced by previous experience, convenience perception, and time barriers, which increase or decrease the perceived level of feasibility of a behavior [64]. Numerous studies reported that PBC has positive effect on intention $[24,65,66]$. It is assumed that a higher level of $\mathrm{PBC}$ will lead to a stronger intention to perform an environmentally friendly behavior. Under the premises of TPB and findings of previous studies, the next hypothesis is as below:

Hypothesis (H11). PBC has a positive effect on ITEFB.

\subsection{Factors Affecting $P B C$}

Ajzen [25] explained that PBC consists of two components, which is perceived control and power beliefs. Perceive control represents a person's perception that he or she has the opportunities or resources to carry out certain behavior, while power beliefs pertain to the extent of a one's perception to utilize the opportunities and resources to achieve a certain outcome. This study contemplated determining the intention and behavior towards EFB adoption. Hence, it focused on start-up resources and skills and knowledge as the important factors to determine PCB.

\subsubsection{Start-Up Resources (SR)}

It is important to have enough resources when setting up any business entities apart from a belief that there is the opportunity to succeed. The availability of resources and opportunities could motivate a person to develop the intention and translate it into behavior. The TPB explained that control beliefs (SR) are important for the development of any intentions [25]. Han, Hsu, and Sheu [58], researched the intention to visit green hotels among general lodging customers and found that control beliefs have a significant positive effect on perceived behavior control. By considering the previous theoretical and empirical findings, the following hypothesis is postulated:

Hypothesis (H12). SR has a positive effect on PBC. 


\subsubsection{Skills and Knowledge (SK)}

SK can be referred to as the extent of a person's knowledge to utilize the opportunities and resources to achieve a certain outcome. When a person has more knowledge on how to utilize available resources and opportunities in achieving something, the person will have a higher level of intention to perform it. As explained by the TPB, intention or behavior is influenced by the person's level of confidence to perform it [63,67]. Han, Hsu, and Sheu [58] found that perceived power can affect the intention to visit green hotels. As a consequence, this study came up with the proposed hypothesis:

Hypothesis (H13). SK has a positive effect on PBC.

\subsection{Mediating Effect of Perceived Behavior Control}

SR and SK are found to have significant positive effect on intention [58]. Several studies [32,62] found that perceived behavior control can affect intention. Therefore, this study intends measuring the mediating effects of PBC between SR and SK with ITEFB. Thus, the following hypotheses were suggested:

Hypothesis (H14). PBC can mediate the effect of SR on the ITEFB.

Hypothesis (H15). PBC can mediate the effect of SK on the ITEFB.

\subsubsection{ITEFB and Environmentally Friendly Business Adoption Behavior (EFBAB)}

A person's intention can be translated to behavior, given that it is a sound intention and achieving it is feasible. Ajzen [25] stated that intention represents a person's MO in the intensity and persistence in performing a behavior. When the intention is stronger, there is a higher possibility to achieve the intended behavior. TPB and its components are almost inevitable in behavioral studies. Moreover, these constructs have been used in various behavioral studies including waste separation behavior [65], purchase intention and behavior towards environmentally friendly vehicles [24], and willingness to pay for environmentally friendly products [66]. All of the three studies found that intention can affect behavior. Hence, this study postulated the following hypothesis:

Hypothesis (H16). ITEFB has a positive effect on EFBAB.

\subsubsection{Mediating Effect of ITEFB}

The TPB and the findings of previous studies presented above illustrated how ATE, SUN, and PBC could affect intention. It was found that ATE $[24,26,29,68]$, SUN $[17,24,55]$, and PBC $[24,65,66]$ can affect intention. It was also found that intention can affect behavior $[24,65,66]$. Therefore, this study intended to measure the mediating effect of ITEFB between ATE, SUN, PBC, and EFBAB. Accordingly, the following hypotheses are presented:

Hypothesis (H17). The ITEFB can mediate the effect of ATE on EFBAB.

Hypothesis (H18). The ITEFB can mediate the effect of SUN on EFBAB.

Hypothesis (H19). The ITEFB can mediate the effect of PBC on EFBAB.

\section{Research Methodology}

The study employed a survey questionnaire, collecting data using a structured questionnaire to examine the impact of explanatory variables on the intention and behavior towards EFB. This study considered low-income households as the population of the study who have income from RM1500 to RM3000 (the median for monthly household income in the rural areas has increased at $5.3 \%$ per 
annum from RM3123 in 2014 to RM3471 in 2016) [69]. This study obtained the database of Malaysian low-income households with specific details including name, address, and contact details from selected Financial Institutions such as Majlis Amanah Rakyat (2690 Households), Majlis Agama Islam dan Adat Istiadat Melayu Kelantan (150 Households), Amanah Ikhtiar Malaysia (158 Households), and e-Kasih under the Implementation and Coordination Unit of the Prime Minister's Department (519 Households) Malaysia.

The team that managed collection of data contacted the selected leader of households to explain the survey's reason or purpose and arranged the appointments for interview before continuing with the fieldwork. The selected respondents were contacted via phone call, as they provided their phone number in their details. This interview was conducted face to face, the purpose and instructions for which are explained, after handing over the questionnaires, and the respondents were asked to write down their views [70]. All of the respondents were representing the low-income households that were willing to contribute to this study through the distribution of questionnaires.

\subsection{Sample Size}

The sample size was calculated using G-Power software (Available: https://www.gpower.hhu.de). It revealed the power of 0.95 , with an effect size of 0.15 , which requires a sample size of 172 to analyze the model with ten constructs. Reinartz, Haenlein, and Henseler [71] mentioned that the minimum sample size of PLS-SEM is 100. This study collected data from 420 low-income households, which is higher than the sample size calculated using G-Power and recommended by Reinartz, Haenlein, and Henseler [71].

\subsection{Research Instrument}

The questionnaire was the main data collection instrument, which was adopted based on past studies with minor modification. The items for enterprise SR were adopted from Clark and Douglas [72]. Perceived benefits and risks were measured using six items adopted from Park and Ohm [73]. The EC scales with six items were adopted from Cheung et al. [31] and Maichum et al. [32]. The EL scale with six indicators was accepted from Maichum et al. [32] and Mostafa [33]. The six items for NBs were adopted from $\mathrm{Wu}$ and Chen [57]. A total of seven items were adopted from Dimov [74] and Benzing et al. [75] to measure MO. The seven items for SR were adopted from Liñán [76] and Miralles et al. [77]. The ATE scale with six items was adopted from Ha and Janda [78] and Maichum et al. [32]. The five items for SUN were adopted from Wu and Chen [57] and Maichum et al. [32], and six items for the PBC scale were adopted from Maichum et al. [32]. The respondents rated their opinion using the five-point Likert scale from strongly disagree (1) to strongly agree (5), except the items for enterprise recourses that used the option of "Yes" or "No".

\subsection{Common Method Variance (CMV)}

In order to avoid single source bias, the researchers stated all items for extraneous variables in a five-point Likert scale, while endogenous variables were stated in a seven-point Likert scale as suggested by Podsakoff et al. [79]. The Harman's one factor test was also executed for CMV as recommended by Podsakoff et al. [79], where one fixed factor extracted from all the main constructions should explain less than $50 \%$ of the variance. The results reveal that one component can explain $30.49 \%$ of the variance, which is below the maximum threshold of $50 \%$. The results also confirm that there is no high correlation between variables that indicate the absence of common method bias [80].

\subsection{Multivariate Normality}

The Web Power online tool was used to test multivariate normality. The Web Power calculates Mardia's multivariate skewness and kurtosis coefficients and $p$-values, which were lower than 0.05 , which confirmed the multivariate non-normality. 


\subsection{Data Analysis Method}

PLS-SEM is a causal modelling approach that aimed to maximize the explained variance of dependent variable [81]. This study employed PLS-SEM because of its exploratory nature and non-normality issue. In order to maximize the explanation of variance PLS-SEM was estimated. The results of the study are in line with the recommendation of Hair, Ringle, and Sarstedt [82] for PLS modelling, that consider reliability, internal consistency, convergent validity, discriminant validity, average variance extracted (AVE), effect size, path coefficient estimates, and predictive relevance.

\section{Summary of Findings}

\subsection{Demographic Profile}

The data were collected from 420 low-income households in the rural areas of Peninsular Malaysia with a total of $56.9 \%$ female and $43.1 \%$ male. Around $65 \%$ of the respondents were in the age range of 31 to 50 years old. Around $80 \%$ completed secondary school and above. More than $60 \%$ respondents have business management experience through earlier employment.

\subsection{Reliability and Validity}

Table 1 exhibits the descriptive statistics of the studied variables as well as reliability of the constructs. To measure internal consistency, "Cronbach's alpha" values are obtained. It indicates that all reliability values are larger than 0.85 , which confirms internal consistency. Apart from the Cronbach's alpha values, composite reliability is also calculated for reliability, which exceeds the cut-off point of 0.7 [81]. In addition, the Dillon-Goldstein rho values for all constructs are more than 0.8 , which further confirm the reliability of the items.

Table 1. Reliability and Validity.

\begin{tabular}{ccccccccc}
\hline Variables & No. Items & Mean & SD & CA & DG rho & CR & AVE & VIF \\
\hline EC & 6 & 4.4032 & 0.56047 & 0.915 & 0.915 & 0.934 & 0.704 & 1.090 \\
EL & 6 & 3.5964 & 0.74315 & 0.928 & 0.931 & 0.944 & 0.736 & 1.090 \\
NB & 6 & 3.7345 & 0.72540 & 0.930 & 0.935 & 0.945 & 0.739 & 1.676 \\
MO & 7 & 3.3745 & 0.74348 & 0.937 & 0.940 & 0.949 & 0.727 & 1.676 \\
SR & 7 & 0.5350 & 0.35830 & 0.853 & 0.875 & 0.886 & 0.528 & 1.090 \\
SK & 7 & 3.1629 & 0.73046 & 0.935 & 0.936 & 0.947 & 0.720 & 1.090 \\
ATE & 6 & 3.7802 & 0.67493 & 0.938 & 0.939 & 0.951 & 0.764 & 1.347 \\
SUN & 5 & 3.4276 & 0.66813 & 0.892 & 0.896 & 0.921 & 0.699 & 1.506 \\
PBC & 7 & 3.3500 & 0.66787 & 0.924 & 0.924 & 0.939 & 0.688 & 1.674 \\
ITGB & 6 & 3.4611 & 0.66373 & 0.933 & 0.934 & 0.947 & 0.749 & 1.000 \\
GBAB & 8 & 4.3271 & 1.01769 & 0.957 & 0.962 & 0.964 & 0.768 & - \\
\hline
\end{tabular}

Note: EC: Environmental Concern; EL: Eco-Literacy; NB: Normative Beliefs; MO: Motivation; SR: Startup Resources; SK: Skills and Knowledge; ATE: Attitude towards Environment; SUN: Subjective Norms; PBC: Perceived Behavioral Control; ITGB: Intention Towards Green Business; GBAB: Green Business Adoption Behavior; SD: Standard Deviation; CA: Cronbach's Alpha; DG rho-Dillon-Goldstein's rho; CR-Composite Reliability; AVE-Average

Variance Extracted; VIF-Variance Inflation Factor; Source: Author's data analysis.

The value of average variance extracted (AVE) must be greater than 0.50 to obtain a convergent validity. Table 1 shows that the AVE values for all constructions are greater than 0.50 , which confirms an existence of convergent validity. This study also tested the variance inflation factors (VIF) for the multicollinearity problem. The VIF values for all the variables are below the 3.33 threshold [83], which indicates the absence of multicollinearity problems.

According to the Fornell-Larcker criterion, in order to have discriminant validity the AVE value of the construct needs to be $\geq 0.50$. Table 2 shows that all constructs exceed the threshold value. The Heterotrait-Monotrait Ratio (HTMT) also confirms discriminant validity, because none of the correctional value do not exceed cut off value of 0.90 . Table A1 shows that all items' loadings are $\geq 0.7$, except for 1 item (SR-6), which has the loading value of 0.648 . The items with standardized loadings of less than 0.7 were kept for further analysis and deleted some items that are below 0.5. Table A1 
also shows that all the items' loadings are larger than the total cross-loadings, which confirmed the discriminant validity.

Table 2. Discriminant Validity.

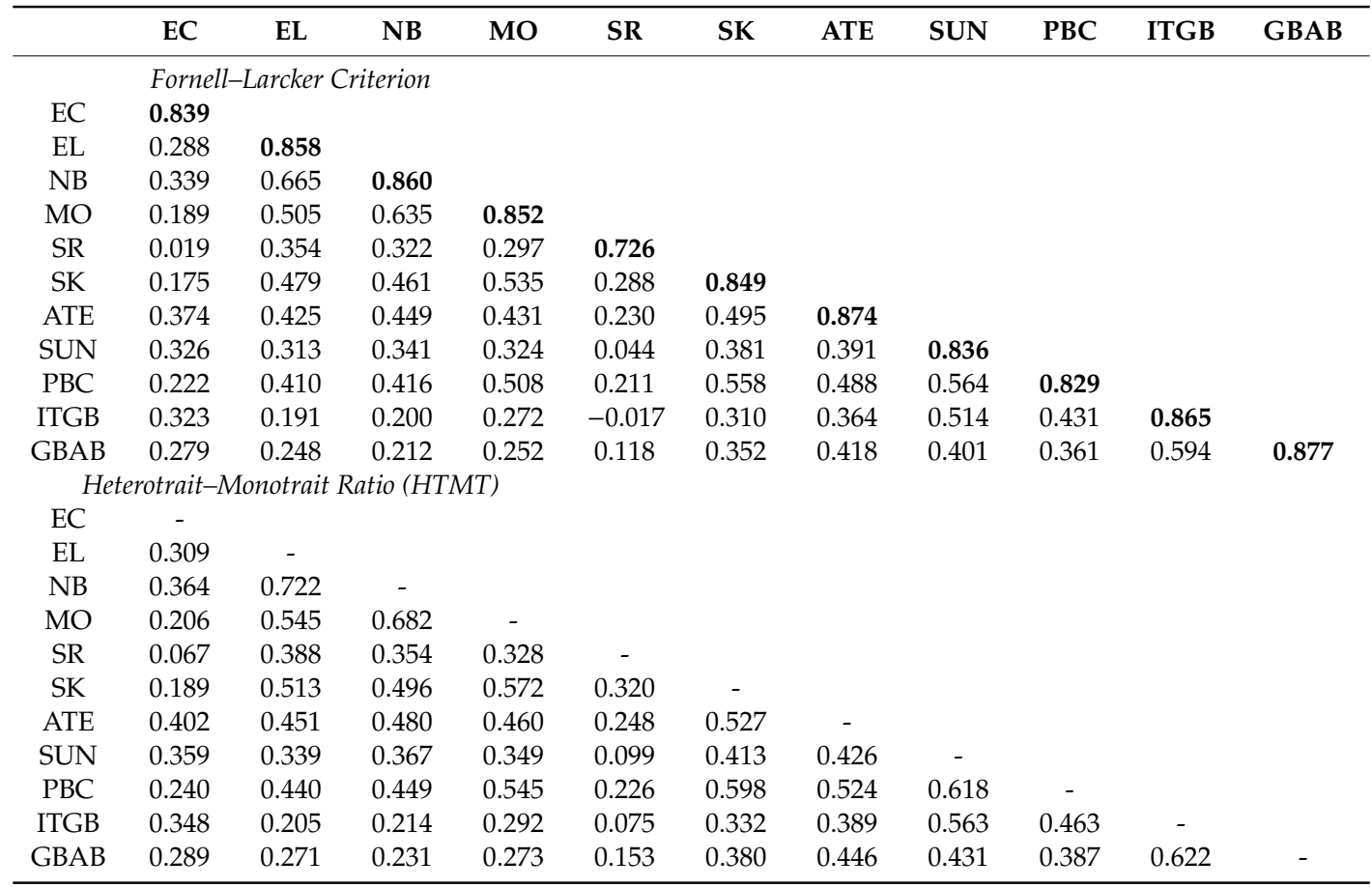

Note: EC: Environmental Concern; EL: Eco-Literacy; NB: Normative Beliefs; MO: Motivation; SR: Startup Resources; SK: Skills and Knowledge; ATE: Attitude towards the Environment; SUN: Subjective Norms; PBC: Perceived Behavioral Control; ITGB: Intention towards Green Business; GBAB: Green Business Adoption Behavior; Source: Author's data analysis.

\subsection{Path Analysis}

Table 3 shows the path coefficients value for EC and EL on the ATE of Malaysian low-income households in rural areas (Hypothesis $2 \& 3$ ) are 0.274 and 0.346 , respectively, with the $p$-value $\leq 0.001$. The results showed that the low-income households' level of EC and EL has a positive effect on their ATE. EL has a bigger effect on the ATE compared to EC. The $r^{2}$ value indicates that a significant proportion of $24.9 \%$ for the variation of respondents' ATE can be described by their level of EC and EL. The $Q^{2}$ value of 0.180 indicates that the respondents' level of EC and EL has medium predictive relevance for the respondents' ATE.

The coefficient values for NB and MO on SUN (Hypothesis $7 \& 8$ ) are 0.227 and 0.179 , respectively, with the $p$-value $=0.05$ at $5 \%$ level of significance. The findings show that the low-income households' level of NB and MO has a positive effect on their SUN. The standardized regression coefficients show that NB has a relatively higher effect on SUN compared to MO. Even though the $f^{2}$ values of 0.036 and 0.022, respectively, show the small effect of NBs and MO on SUN, the NBs have a relatively bigger effect on SUN. The $r^{2}$ value is 0.136 , which indicates the proportion of $13.6 \%$ for the variation in respondents' SUN, which can be explained by their level of NBs and MO. The value of $Q^{2}$ indicates that the respondents' level of NBs and MO has medium predictive relevance $\left(Q^{2}=0.205\right)$ shown for the respondents' SUN. 
Table 3. Path Coefficients.

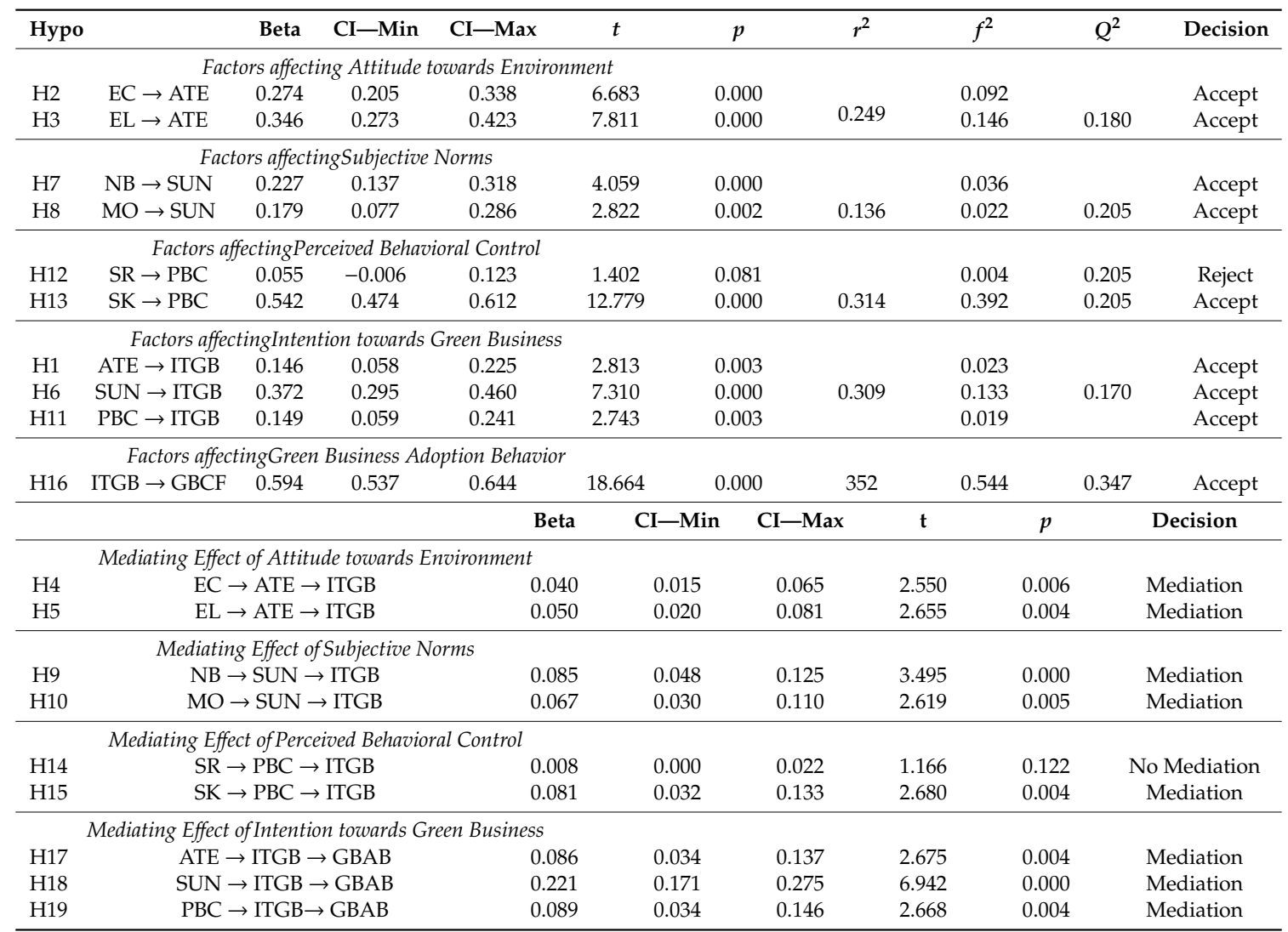

Note: EC: Environmental Concern; EL: Eco-Literacy; NB: Normative Belief; MO: Motivation; SR: Startup Resources; SK: Skills and Knowledge; ATE: Attitude towards the Environment; SUN: Subjective Norms; PBC: Perceived Behavioral Control; ITGB: Intention towards Green Business; GBAB: Green Business Adoption Behavior; Source: Author's data analysis.

The coefficient value for the SR on perceived behavior control is 0.055 with the $p$-value of 0.081 at the $5 \%$ significance level. The findings indicate that low-income households' level of SR has a positive but insignificant effect on their perceived behavior control (Hypothesis 12). SK on perceived control behavior (Hypothesis 13) has the coefficient value of 0.542 with $p$-value of less than 0.05 , which indicates a positive and significant effect. The standardized regression coefficients show that SK have a larger effect compared to SR. The $f^{2}$ value of 0.004 shows a very small effect of SR, and 0.392 indicates a large effect of SR on perceived behavior control. The $r^{2}$ value is 0.314 with a proportion of $31.4 \%$ for the variation in respondents' perceived behavior control, which can be explained by their level of SR and skills and knowledge. The values of $Q^{2}$ indicate that the respondents' level of SR and SK has medium predictive relevance $\left(Q^{2}=0.205\right)$ for the respondents' perceived behavior control.

In predicting the ITEFB among the poor families in the rural areas in Malaysia, it was found that the ATE, SUN, and PBC (Hypothesis 1, 6 \& 11) have the coefficient values of 0.146, 0.372, and 0.149, respectively, with the $p$-values of less than 0.05 (more than the $5 \%$ level of significance). It implies that all of them have positive and significant effects on intention. Based on the $f^{2}$ value, all three variables have a small effect size on the ITEFB. The $Q^{2}$ reflects that the respondents' level of ATE, SUN, and perceived behavior control has medium predictive relevance $\left(Q^{2}=0.170\right)$ on the respondents' ITEFB. The $r^{2}$ value indicates that $30.9 \%$ of variation in respondents' intention is explained by the ATE, SUN, and perceived behavior control.

The 16th hypothesis of this study tested the effect of ITEFB on EFBAB. The path coefficient of this relationship is 0.594 with the $p$-value $\leq 0.001$, which means that intention has a positive and significant effect on behavior. The ITEFB has a large effect on the EFBAB $\left(f^{2}=0.544\right)$ and above the medium level 
of predictive relevance $\left(Q^{2}=0.347\right)$. The $r^{2}$ indicates that $35.2 \%$ of variance in the adoption behavior is explained by the ITEFB.

\subsection{Mediating Effects}

This section presents the mediating effects of ATE, SUN, perceived behavior control, and ITEFB. Table 3 presents the findings that revealed EC (Hypothesis 4) and EL (Hypothesis 5) have significant indirect effect on ITEFB ( $p$-value < 0.05). It can be said that the ATE can mediate the relationship between EC, EL, and ITEFB. Both NBs (Hypothesis 9) and MO (Hypothesis 10) have significant indirect effects on the ITEFB. It is revealed that SUN can mediate the relationship between NBs, MO, and ITEFB. For the mediating effect of PBC, the SR (Hypothesis 14) have insignificant indirect effect ( $p$-value $>0.05$ ), while SR (Hypothesis 15) have significant indirect effect on the ITEFB. There is a mediating effect of PBC between SR and intention, while the relationship between SR and intention is not mediated. It was found that the ATE (Hypothesis 17), SUN (Hypothesis 18), and PBC (Hypothesis 19) have significant indirect effect on the EFBAB. It is proven that the ITEFB can mediate the relationship between the ATE, SUN, PBC, and EFBAB.

\subsection{Importance-Performance Matrix Analysis (IPMA)}

IPMA was employed for the ITEFB and EFBAB as the target constructs. The importance score refers to the total effect values, and performance values indicate the level of performance of the constructs, as shown in Table 4. IPMA scores range from 0 "low performance" to 100 "highest performance". The findings showed that EC, NBs, and SUN are the outmost significant determinants that can impact the ITEFB and EFBAB.

Table 4. Performance and Total Effects.

\begin{tabular}{ccccc}
\hline Target Construct & Intention towards Green Business & \multicolumn{2}{c}{ Green Business Adoption Behavior } \\
\hline Variables & Total Effect & Performance & Total Effect & Performance \\
\hline Environmental Concern & 0.047 & 81.158 & 0.043 & 0.041 \\
\hline Eco-Literacy & 0.045 & 62.797 & 0.071 & 62.797 \\
\hline Normative Beliefs & 0.078 & 66.655 & 0.054 & 66.655 \\
\hline Motivation & 0.060 & 49.826 & 0.014 & 59.826 \\
\hline Start-up Resources & 0.015 & 53.446 & 53.446 \\
\hline Skills and Knowledge & 0.074 & 54.078 & 0.131 & 54.078 \\
\hline Attitude towards Environment & 0.143 & 59.266 & 6.338 & 59.266 \\
\hline Subjective Norms & 0.369 & 60.596 & 50.596 \\
\hline Intention towards Green Business & - & 58.764 & 0.915 & 58.764 \\
\hline
\end{tabular}

Source: Author's data analysis.

\section{Discussion and Implication}

The focal study aimed to investigate the key determinants that can influence the poor households intention and behavior towards EFB in the rural areas in Malaysia. This study is motivated by the previous research on green efforts that highlighted three main areas such as (1) green supply chain [14,15], (2) green purchasing [16-20], and (3) green vehicles [21-24]. The EFB concepts should incorporate the aspects of poverty such as low-working capital, lack of education or skills, and a relatively lower level of entrepreneurial competencies, because this study focused on the potentials of EFB to eradicate poverty. This study could not obtain any empirical papers that focused on feasibility analysis and recommended a low-cost business model for the poor.

The finding revealed that EC and EL have significant positive effect on the ATE. Individuals and households with high level of EC and EL tend to have positive ATE. This finding has strengthened the 
theory that is in compliance with the prior findings of Qader and Zainuddin [34], Chen and Tung [44], and Cabuk, Tanrikulu, and Gelibolu [45]. The confirmation of the hypothesis has provided insight into the determination of ATE among low-income rural households. The governments should give more information on the effect of negative ATE and create regulations to ensure that the green products and services are labelled and conveyed to the public. The knowledge and interest in the environment could assist the government's initiatives to achieve sustainable development.

It was noted that a similar relationship is observed between NBs, MO, and SUN. The findings are similar to the findings from earlier studies on the TPB model such as Tan et al. (2012) and Hernandez and Mazzon [61]. It is proven that social pressure from family and friends could influence the SUN of the respondents. Apart from that, this study considered that the internal factor, which is $\mathrm{MO}$, is influential. The belief that a person can contribute to the betterment of the environment can act as a good motivator to practice environmentally friendly behavior.

It was found that PBC can be influenced by SR and not by SR. The TPB affirmed that control beliefs and perceived power could influence the perceived behavior control. Though SK are in compliance with the theory and prior findings of Baker et al. [67] and Han, Hsu, and Sheu [58], SR are found to be contradicting. It means that the perception of having access to SR such as internet, ideas, marketing expertise, advertising, and expert opinions on technical matters and finance and accounting could not convince others to become environmentally friendly. Several previous studies predicted that the availability of resources, technologies, and government support has significant positive influence on customer's perceived behavior control, specifically their intention to adopt internet banking. When there is the presence of self-efficacy with resources in which technologies and government support are used to predict $\mathrm{PBC}$, self-efficacy was reported as significant and positive. Hence, self-efficacy is considered a strong predictor of $P B C$.

In predicting the ITEFB, all three variables of TPB, which are ATE, SUN, and PBC, were found to be significant and positive, while SUN are considered as the biggest influencer. The findings are consistent with the previous findings of Laroche et al. [68], Paladino and Baggiere [29], Vermeir and Verbeke [17], Chen [55], Oliver and Lee [26], Afroz et al. [23], Zhang et al. [65], Afroz et al. [24], and Al Mamun et al. [66]. This finding has strengthened the theory of TPB and provided empirical evidence on the effects of the ITEFB among low-income families. The government agencies should consider communicating the importance of being environmentally friendly, creating socially responsible community towards environment, and empowering low-income households with resources to be environmentally friendly in promoting EFB. This effort could increase the possibility of others adopting EFB. This study found that the effort could be translated into behavior in which the ITEFB can significantly affect the EFBAB. Ajzen [25] explained that the intention and perception of control must be compatible to predict a set of behaviors. In this case, the intention was to initiate EFB. This study has confirmed the theory and findings of earlier studies.

This study has presented the mediating effects within the TPB model and found that ATE can mediate the relationship between EC, EL, and ITEFB. SUN can mediate the relationship between NBs, $\mathrm{MO}$, and ITEFB, while PBC can mediate the relationship between SR with the intention towards EFB. It was found that the ITEFB can mediate the relationship between the ATE, SUN, PBC, and EFBAB.

\section{Conclusions}

Overall, it was found that the ATE, SUN, and PBC were able to determine the behavioral outcomes. Therefore, this study has investigated the determinants that influence the intention and behaviors towards EFB among poor families in the rural areas in Malaysia. Overall, the findings suggested that the TPB model could explain the relationship as well as the cause and effect in achieving the EFBAB. This study has filled up the gaps in the literature by expanding the existing findings that focus on the "green supply chain, green purchasing and green vehicles". The results indicate that the proposed research framework will be a good model in promoting the EFB to eradicate poverty. This study has presented the practical implication from the EFB development aspect in which the government 
and agencies work on the presented model to develop EFB. At the same time, the awareness of environmental issues should be increased, and the cultivation of positive ATE should be embarked upon. Additionally, the development that is solely on EFB is not sustainable if there is no need for green products and services. The presence of increased and stable demand could make it possible for EFB sustainability that will lead to a sustainable green economy. Accordingly, it sheds some light on achieving the results between environmental management and economic performance towards sustainability. Indeed, it represents the qualities of management concepts that focus on market development by reducing costs and increasing eco-efficiency.

This study was limited to poor families in the rural areas without considering other populations from other income levels and urban areas. For the intention to translate into behaviors, it will take more time, and the outcomes might not be desirable. A cross-sectional design was adopted in this research, which limited the researchers to obtain more varied behavior responses. Given the wide range of potential for environmentally friendly business and the limited theoretical and empirical research that has been conducted to date on the intention and behavior, research broadening the investigation to include other potential variables is required. Based on the limitations, it is recommended that future researchers should address other income groups and the rural-urban gap, as well as adopting a longitudinal study to determine whether the investigation could provide a different picture of intention and behavior. On the other hand, the research could select samples from other countries and higher education settings. This would enable comparisons to the current study and provide more comprehensive perspectives on EFB. This study found that SR is an insignificant predictor of PBC. Hence, future researchers should consider the self-efficacy part in the equation to investigate whether the predictor could provide changes in the relationship.

Author Contributions: K.M.M., N.C.N., R.M., and N.R.Z. focused on conceptualization, methodology, resources, and writing-original draft preparation; A.A.M. and M.M.M. focused on conceptualization, methodology, supervision, and writing-review and editing. All authors have read and agreed to the published version of the manuscript.

Funding: This research was funded by the Ministry of Education, Malaysia under the grant entitled "Developing a Comprehensive Rural Entrepreneurship Model for Poverty Eradication (REMODE)" (R/NRGS/A01.00/00047A/006/2014/000149).

Conflicts of Interest: The authors declare no conflict of interest.

\section{Appendix A}

Table A1. Loadings and Cross-Loading.

\begin{tabular}{|c|c|c|c|c|c|c|c|c|c|c|c|}
\hline & EC & EL & NB & MO & SR & SK & ATE & SUN & PBC & ITGB & GBAB \\
\hline EC-Item 1 & 0.740 & 0.273 & 0.295 & 0.187 & 0.080 & 0.185 & 0.330 & 0.263 & 0.276 & 0.301 & 0.227 \\
\hline EC-Item 2 & 0.813 & 0.290 & 0.327 & 0.183 & 0.065 & 0.121 & 0.310 & 0.272 & 0.244 & 0.255 & 0.224 \\
\hline EC-Item 3 & 0.862 & 0.239 & 0.273 & 0.162 & 0.020 & 0.110 & 0.311 & 0.291 & 0.181 & 0.283 & 0.254 \\
\hline EC-Item 4 & 0.874 & 0.214 & 0.277 & 0.136 & -0.023 & 0.141 & 0.291 & 0.270 & 0.121 & 0.253 & 0.213 \\
\hline EC-Item 5 & 0.873 & 0.217 & 0.277 & 0.137 & -0.028 & 0.157 & 0.325 & 0.264 & 0.141 & 0.268 & 0.243 \\
\hline EC-Item 6 & 0.862 & 0.206 & 0.250 & 0.141 & -0.026 & 0.163 & 0.305 & 0.279 & 0.143 & 0.259 & 0.236 \\
\hline EL-Item 1 & 0.254 & 0.827 & 0.562 & 0.404 & 0.284 & 0.378 & 0.357 & 0.301 & 0.343 & 0.161 & 0.186 \\
\hline EL-Item 2 & 0.279 & 0.853 & 0.568 & 0.427 & 0.320 & 0.421 & 0.413 & 0.306 & 0.383 & 0.179 & 0.215 \\
\hline EL-Item 3 & 0.263 & 0.881 & 0.544 & 0.419 & 0.290 & 0.405 & 0.381 & 0.275 & 0.352 & 0.188 & 0.235 \\
\hline EL-Item 4 & 0.269 & 0.870 & 0.584 & 0.440 & 0.281 & 0.391 & 0.334 & 0.227 & 0.328 & 0.133 & 0.235 \\
\hline EL-Item 5 & 0.220 & 0.860 & 0.573 & 0.429 & 0.327 & 0.424 & 0.359 & 0.226 & 0.349 & 0.165 & 0.217 \\
\hline EL-Item 6 & 0.187 & 0.855 & 0.596 & 0.484 & 0.318 & 0.446 & 0.329 & 0.268 & 0.346 & 0.152 & 0.185 \\
\hline NB-Item 1 & 0.278 & 0.640 & 0.846 & 0.554 & 0.327 & 0.426 & 0.400 & 0.250 & 0.374 & 0.156 & 0.193 \\
\hline NB-Item 2 & 0.263 & 0.612 & 0.839 & 0.533 & 0.323 & 0.389 & 0.361 & 0.240 & 0.363 & 0.146 & 0.122 \\
\hline NB-Item 3 & 0.366 & 0.552 & 0.856 & 0.552 & 0.243 & 0.395 & 0.459 & 0.313 & 0.345 & 0.196 & 0.225 \\
\hline
\end{tabular}


Table A1. Cont.

\begin{tabular}{|c|c|c|c|c|c|c|c|c|c|c|c|}
\hline & EC & EL & NB & MO & SR & SK & ATE & SUN & PBC & ITGB & GBAB \\
\hline NB-Item 4 & 0.371 & 0.537 & 0.852 & 0.500 & 0.219 & 0.357 & 0.392 & 0.314 & 0.286 & 0.189 & 0.186 \\
\hline NB-Item 5 & 0.257 & 0.569 & 0.891 & 0.572 & 0.274 & 0.414 & 0.359 & 0.322 & 0.399 & 0.192 & 0.202 \\
\hline NB-Item 6 & 0.205 & 0.548 & 0.874 & 0.568 & 0.299 & 0.404 & 0.346 & 0.302 & 0.386 & 0.145 & 0.155 \\
\hline MO-Item 1 & 0.170 & 0.393 & 0.475 & 0.766 & 0.204 & 0.426 & 0.278 & 0.273 & 0.400 & 0.256 & 0.136 \\
\hline MO-Item 2 & 0.189 & 0.445 & 0.515 & 0.785 & 0.170 & 0.435 & 0.294 & 0.246 & 0.401 & 0.233 & 0.197 \\
\hline MO-Item 3 & 0.202 & 0.466 & 0.562 & 0.830 & 0.268 & 0.447 & 0.395 & 0.250 & 0.413 & 0.223 & 0.245 \\
\hline MO-Item 4 & 0.123 & 0.431 & 0.553 & 0.895 & 0.267 & 0.466 & 0.398 & 0.295 & 0.482 & 0.274 & 0.274 \\
\hline MO-Item 5 & 0.168 & 0.433 & 0.583 & 0.901 & 0.279 & 0.468 & 0.404 & 0.292 & 0.459 & 0.228 & 0.219 \\
\hline MO-Item 6 & 0.132 & 0.408 & 0.544 & 0.893 & 0.281 & 0.487 & 0.383 & 0.305 & 0.439 & 0.213 & 0.222 \\
\hline MO_-Item 7 & 0.156 & 0.448 & 0.559 & 0.885 & 0.294 & 0.462 & 0.413 & 0.260 & 0.429 & 0.196 & 0.209 \\
\hline SR-Item 1 & 0.046 & 0.270 & 0.242 & 0.154 & 0.759 & 0.169 & 0.161 & 0.031 & 0.152 & -0.036 & 0.049 \\
\hline SR-Item 2 & 0.040 & 0.276 & 0.265 & 0.193 & 0.798 & 0.219 & 0.176 & 0.036 & 0.194 & 0.006 & 0.121 \\
\hline SR-Item 3 & -0.063 & 0.295 & 0.272 & 0.309 & 0.784 & 0.226 & 0.217 & -0.037 & 0.191 & -0.108 & 0.058 \\
\hline SR-Item 4 & 0.018 & 0.296 & 0.279 & 0.227 & 0.753 & 0.264 & 0.190 & 0.071 & 0.164 & -0.017 & 0.061 \\
\hline SR-Item 5 & 0.033 & 0.176 & 0.145 & 0.181 & 0.589 & 0.151 & 0.075 & 0.074 & 0.095 & 0.027 & 0.119 \\
\hline SR-Item 6 & 0.034 & 0.210 & 0.168 & 0.179 & 0.648 & 0.187 & 0.147 & 0.098 & 0.104 & 0.082 & 0.134 \\
\hline SR-Item 7 & 0.014 & 0.242 & 0.217 & 0.257 & 0.729 & 0.239 & 0.166 & -0.001 & 0.126 & 0.032 & 0.099 \\
\hline SK-Item 1 & 0.102 & 0.314 & 0.323 & 0.403 & 0.190 & 0.779 & 0.334 & 0.356 & 0.450 & 0.266 & 0.247 \\
\hline SK-Item 2 & 0.123 & 0.363 & 0.358 & 0.435 & 0.189 & 0.829 & 0.419 & 0.385 & 0.511 & 0.295 & 0.299 \\
\hline SK-Item 3 & 0.163 & 0.419 & 0.420 & 0.458 & 0.215 & 0.849 & 0.399 & 0.346 & 0.453 & 0.260 & 0.270 \\
\hline SK-Item 4 & 0.148 & 0.405 & 0.418 & 0.475 & 0.291 & 0.872 & 0.400 & 0.286 & 0.454 & 0.275 & 0.313 \\
\hline SK-Item 5 & 0.165 & 0.445 & 0.415 & 0.455 & 0.268 & 0.898 & 0.437 & 0.295 & 0.467 & 0.276 & 0.346 \\
\hline SK-Item 6 & 0.163 & 0.445 & 0.397 & 0.466 & 0.278 & 0.865 & 0.459 & 0.294 & 0.481 & 0.239 & 0.318 \\
\hline SK-Item 7 & 0.176 & 0.448 & 0.405 & 0.484 & 0.280 & 0.844 & 0.481 & 0.299 & 0.487 & 0.229 & 0.294 \\
\hline ATE-Item 1 & 0.285 & 0.403 & 0.385 & 0.413 & 0.259 & 0.442 & 0.833 & 0.305 & 0.411 & 0.264 & 0.364 \\
\hline ATE-Item 2 & 0.295 & 0.436 & 0.422 & 0.446 & 0.250 & 0.468 & 0.843 & 0.352 & 0.456 & 0.315 & 0.405 \\
\hline ATE-Item 3 & 0.341 & 0.316 & 0.371 & 0.376 & 0.151 & 0.402 & 0.863 & 0.350 & 0.419 & 0.316 & 0.386 \\
\hline ATE-Item 4 & 0.322 & 0.313 & 0.351 & 0.333 & 0.206 & 0.428 & 0.896 & 0.326 & 0.408 & 0.337 & 0.359 \\
\hline ATE-Item 5 & 0.359 & 0.380 & 0.414 & 0.332 & 0.181 & 0.426 & 0.906 & 0.350 & 0.415 & 0.331 & 0.354 \\
\hline ATE-Item 6 & 0.354 & 0.373 & 0.406 & 0.359 & 0.162 & 0.427 & 0.900 & 0.361 & 0.446 & 0.341 & 0.328 \\
\hline SUN-Item 1 & 0.196 & 0.174 & 0.217 & 0.214 & -0.007 & 0.261 & 0.274 & 0.803 & 0.407 & 0.440 & 0.269 \\
\hline SUN-Item 2 & 0.196 & 0.256 & 0.284 & 0.266 & 0.024 & 0.290 & 0.316 & 0.838 & 0.462 & 0.396 & 0.332 \\
\hline SUN-Item 3 & 0.378 & 0.226 & 0.230 & 0.170 & -0.004 & 0.245 & 0.353 & 0.802 & 0.375 & 0.461 & 0.388 \\
\hline SUN-Item 4 & 0.312 & 0.323 & 0.338 & 0.335 & 0.074 & 0.389 & 0.347 & 0.881 & 0.547 & 0.462 & 0.372 \\
\hline SUN-Item 5 & 0.275 & 0.316 & 0.345 & 0.352 & 0.085 & 0.393 & 0.340 & 0.854 & 0.552 & 0.388 & 0.311 \\
\hline PBC-Item 1 & 0.233 & 0.263 & 0.287 & 0.357 & 0.112 & 0.410 & 0.383 & 0.524 & 0.746 & 0.368 & 0.310 \\
\hline PBC-Item 2 & 0.249 & 0.334 & 0.348 & 0.390 & 0.150 & 0.460 & 0.407 & 0.557 & 0.779 & 0.420 & 0.339 \\
\hline PBC-Item 3 & 0.131 & 0.322 & 0.308 & 0.436 & 0.141 & 0.442 & 0.370 & 0.429 & 0.829 & 0.383 & 0.294 \\
\hline PBC-Item 4 & 0.205 & 0.386 & 0.365 & 0.440 & 0.172 & 0.475 & 0.432 & 0.430 & 0.851 & 0.331 & 0.287 \\
\hline PBC-Item 5 & 0.229 & 0.362 & 0.403 & 0.470 & 0.223 & 0.498 & 0.428 & 0.439 & 0.852 & 0.325 & 0.291 \\
\hline PBC-Item 6 & 0.120 & 0.358 & 0.348 & 0.434 & 0.187 & 0.479 & 0.415 & 0.445 & 0.881 & 0.343 & 0.299 \\
\hline PBC-Item 7 & 0.118 & 0.345 & 0.348 & 0.414 & 0.233 & 0.466 & 0.392 & 0.447 & 0.859 & 0.324 & 0.269 \\
\hline ITGB-Item 1 & 0.227 & 0.173 & 0.193 & 0.262 & 0.010 & 0.265 & 0.297 & 0.408 & 0.330 & 0.808 & 0.485 \\
\hline ITGB-Item 2 & 0.269 & 0.198 & 0.195 & 0.244 & 0.005 & 0.271 & 0.335 & 0.400 & 0.368 & 0.837 & 0.518 \\
\hline ITGB-Item 3 & 0.292 & 0.140 & 0.137 & 0.200 & -0.042 & 0.266 & 0.341 & 0.494 & 0.398 & 0.884 & 0.523 \\
\hline ITGB-Item 4 & 0.320 & 0.167 & 0.187 & 0.227 & -0.048 & 0.259 & 0.313 & 0.456 & 0.374 & 0.879 & 0.493 \\
\hline ITGB-Item 5 & 0.288 & 0.152 & 0.174 & 0.233 & -0.016 & 0.255 & 0.307 & 0.445 & 0.359 & 0.887 & 0.517 \\
\hline ITGB-Item 6 & 0.279 & 0.166 & 0.159 & 0.252 & 0.006 & 0.293 & 0.298 & 0.459 & 0.403 & 0.893 & 0.544 \\
\hline GBAB-Item 1 & 0.144 & 0.287 & 0.263 & 0.273 & 0.162 & 0.378 & 0.384 & 0.324 & 0.319 & 0.413 & 0.796 \\
\hline GBAB-Item 2 & 0.154 & 0.297 & 0.270 & 0.280 & 0.159 & 0.390 & 0.400 & 0.333 & 0.349 & 0.428 & 0.806 \\
\hline GBAB-Item 3 & 0.192 & 0.287 & 0.246 & 0.295 & 0.178 & 0.391 & 0.415 & 0.311 & 0.347 & 0.505 & 0.878 \\
\hline GBAB-Item 4 & 0.259 & 0.248 & 0.204 & 0.217 & 0.120 & 0.299 & 0.348 & 0.332 & 0.295 & 0.527 & 0.930 \\
\hline GBAB-Item 5 & 0.254 & 0.203 & 0.149 & 0.200 & 0.098 & 0.293 & 0.351 & 0.347 & 0.322 & 0.532 & 0.933 \\
\hline GBAB-Item 6 & 0.246 & 0.193 & 0.161 & 0.235 & 0.085 & 0.304 & 0.376 & 0.380 & 0.355 & 0.564 & 0.913 \\
\hline GBAB-Item 7 & 0.324 & 0.139 & 0.129 & 0.158 & 0.028 & 0.231 & 0.335 & 0.387 & 0.278 & 0.584 & 0.879 \\
\hline GBAB-Item 8 & 0.330 & 0.139 & 0.119 & 0.152 & 0.044 & 0.237 & 0.351 & 0.384 & 0.285 & 0.568 & 0.867 \\
\hline
\end{tabular}

Note: (1) EC: Environmental Concern; EL: Eco-Literacy; NB: Normative Belief; MO: Motivation; SR: Startup Resources; SK: Skills and Knowledge; ATE: Attitude towards the Environment; SUN: Subjective Norms; PBC: Perceived Behavioral Control; ITGB: Intention towards Green Business; GBAB: Green Business Adoption Behavior. (2) The italic values in the matrix above are the item loadings and others are cross-loadings; Source: Author's data analysis. 


\section{References}

1. Lee, H.-A.; Khalid, M.A. Is inequality in Malaysia really going down? FEA Working Paper 2014/09, Faculty of Economics Administration, University of Malaya. Available online: https://pdfs.semanticscholar.org/6928/a163ae d1842eeb4cceaf42c1e3d441e5ecf6.pdf?_ga=2.164749503.1007459143.1599299997-336864463.1595552818 (accessed on 5 September 2020).

2. Abdullah, L. Poverty Lines Based on Fuzzy Sets Theory and its Application to Malaysian Data. Soc. Indic. Res. 2010, 104, 117-127. [CrossRef]

3. Saari, M.; Dietzenbacher, E.; Los, B. Sources of Income Growth and Inequality Across Ethnic Groups in Malaysia, 1970-2000. World Dev. 2015, 76, 311-328. [CrossRef]

4. Vaghefi, N.; Siwar, C.; Aziz, S.A.A.G. A Framework for Green Growth and Socio-Economic Development in Malaysia. Curr. World Environ. 2015, 10, 29-38. [CrossRef]

5. IPCC, 2007: Climate Change 2007: Impacts, Adaptation and Vulnerability. Contribution of Working Group II to the Fourth Assessment Report of the Intergovernmental Panel on Climate Change. Available online: https://www.ipcc.ch/site/assets/uploads/2018/03/ar4-wg2-intro.pdf (accessed on 5 September 2020).

6. Masud, M.; Kari, F.; Binti Yahaya, S.; Al-Amin, A. Impact of residents' livelihoods on attitudes towards environmental conservation behaviour: An empirical investigation of Tioman Island Marine Park area, Malaysia. Ocean. Coast. Manag. 2014, 93, 7-14. [CrossRef]

7. Stern, N. The economics of climate change: The Stern Review. Cambridge University Press: Cambridge, UK, 2007.

8. Masud, M.; Akhtar, R.; Afroz, R.; Al-Amin, A.; Kari, F. Pro-environmental behavior and public understanding of climate change. Mitig. Adapt. Strateg. Glob. Chang. 2015, 20, 591-600. [CrossRef]

9. Yee, S.; Carriger, J.; Bradley, P.; Fisher, W.; Dyson, B. Developing scientific information to support decisions for sustainable coral reef ecosystem services. Ecol. Econ. 2015, 115, 39-50. [CrossRef]

10. Bardsley, D.; Hugo, G. Migration and climate change: Examining thresholds of change to guide effective adaptation decision-making. Popul. Environ. 2010, 32, 238-262. [CrossRef]

11. Yaacob, M.R. A preliminary study of micro-entrepreneurs in Kelantan, Malaysia. Int. J. Bus. Manag. 2010, 5, 81-88.

12. ILO-International Labour Organization. Green Business Booklet; International Labour Office: Geneva, Switzerland, 2017.

13. Mufidah, I.; Jiang, B.C.; Lin, S.C.; Chin, J.; Rachmaniati, Y.P.; Persada, S.F. Understanding the consumers' behavior intention in using green ecolabel product through pro-environmental planned behavior model in developing and developed regions: Lessons learned from Taiwan and Indonesi. Sustainabilit 2018, 10, 1423. [CrossRef]

14. Vachon, S.; Klassen, R. Green project partnership in the supply chain: The case of the package printing industry. J. Clean. Prod. 2006, 14, 661-671. [CrossRef]

15. Vachon, S.; Klassen, R. Environmental management and manufacturing performance: The role of collaboration in the supply chain. Int. J. Prod. Econ. 2008, 111, 299-315. [CrossRef]

16. Sen, S.; Bhattacharya, C. Does Doing Good Always Lead to Doing Better? Consumer Reactions to Corporate Social Responsibility. J. Mark. Res. 2001, 38, 225-243. [CrossRef]

17. Vermeir, I.; Verbeke, W. Sustainable Food Consumption: Exploring the Consumer "Attitude-Behavioral Intention" Gap. J. Agric. Environ. Ethics 2006, 19, 169-194. [CrossRef]

18. Bhattacharya, C.; Sen, S. Doing Better at Doing Good: When, Why, and How Consumers Respond to Corporate Social Initiatives. Calif. Manag. Rev. 2004, 47, 9-24. [CrossRef]

19. Ramayah, T.; Lee, J.; Mohamad, O. Green product purchase intention: Some insights from a developing country. Resour. Conserv. Recycl. 2010, 54, 1419-1427. [CrossRef]

20. Zhang, H.; Lahr, M.; Bi, J. Challenges of green consumption in China: A household energy use perspective. Econ. Syst. Res. 2016, 28, 183-201. [CrossRef]

21. Heffner, R.; Kurani, K.; Turrentine, T. Symbolism in California's early market for hybrid electric vehicles. Transp. Res. Part D Transp. Environ. 2007, 12, 396-413. [CrossRef]

22. Gallagher, K.; Muehlegger, E. Giving green to get green? Incentives and consumer adoption of hybrid vehicle technology. J. Environ. Econ. Manag. 2011, 61, 1-15. [CrossRef] 
23. Afroz, R.; Rahman, A.; Masud, M.M.; Akhtar, R.; Duasa, J.B. How Individual Values and Attitude Influence Consumers' Purchase Intention of Electric Vehicles-Some Insights from Kuala Lumpur, Malaysia. Environ. Urban. ASIA 2015, 6, 1-18. [CrossRef]

24. Afroz, R.; Masud, M.; Akhtar, R.; Islam, M.; Duasa, J. Consumer purchase intention towards environmentally friendly vehicles: An empirical investigation in Kuala Lumpur, Malaysia. Environ. Sci. Pollut. Res. 2015, 22, 16153-16163. [CrossRef]

25. Ajzen, I. The theory of planned behavior. Organ. Behav. Hum. Decis. Process. 1991, 50, 179-211. [CrossRef]

26. Oliver, J.; Lee, S. Hybrid car purchase intentions: A cross-cultural analysis. J. Consum. Mark. 2010, $27,96-103$. [CrossRef]

27. Alonso, A.D.; Krajsic, V. The theory of planned behaviour, micro-growers and diversification: An exploratory study. J. Enterp. Communities People Places Glob. Econ. 2015, 9, 94-113.

28. Domina, T.; Koch, K. Convenience And Frequency Of Recycling: Implications for Including Textiles in Curbside Recycling Programs. Environ. Behav. 2002, 34, 216-238.

29. Paladino, A.; Baggiere, J. Are We "Green? An Empirical Investigation of Renewable Electricity Consumption. In European Advances in Consumer Research; Borghini, S., McGrath, M.A., Otnes, C., Eds.; Association for Consumer Research: Duluth, MN, USA, 2007; Volume 8, pp. 340-341.

30. Galati, A.; Gianguzzi, G.; Tinervia, S.; Crescimanno, M.; Veca, D.S.L.M. Motivations, adoption and impact of voluntary environmental certification in the Italian Forest based industry: The case of the FSC standard. For. Policy Econ. 2017, 83, 169-176. [CrossRef]

31. Cheung, R.; Lau, M.; Lam, A. Factors affecting consumer attitude towards organic food: An empirical study in Hong Kong. J. Glob. Sch. Mark. Sci. 2015, 25, 216-231. [CrossRef]

32. Maichum, K.; Parichatnon, S.; Peng, K. Application of the Extended Theory of Planned Behavior Model to Investigate Purchase Intention of Green Products among Thai Consumers. Sustainability 2016, 8, 1077. [CrossRef]

33. Mostafa, M. Antecedents of Egyptian Consumers' Green Purchase Intentions. J. Int. Consum. Mark. 2006, 19, 97-126. [CrossRef]

34. Qader, I.; Zainuddin, Y. The Influences of Media Exposure, Safety and Health Concerns, and Self-Efficacy on Environmental Attitudes towards Electronic Green Products. Asian Acad. Manag. J. 2011, 16, 167-186.

35. Bandura, A. Self-efficacy: Toward a unifying theory of behavioral change. Psychol. Rev. 1977, 84, $191-215$. [CrossRef]

36. Zelezny, L.C.; Schultz, P. Promoting Environmentalism. J. Soc. Issues. 2000, 56, 365-371. [CrossRef]

37. Fraj, E.; Martínez, E. Impact of Environmental Knowledge on Ecological Consumer Behaviour. J. Int. Consum. Mark. 2007, 19, 73-102. [CrossRef]

38. Gil, J.M.; Gracia, A.; Sanchez, M. Market segmentation and willingness to pay for organic products in Spain. Int. Food Agribus. Manag. Rev. 2000, 3, 207-226. [CrossRef]

39. Minton, A.; Rose, R. The Effects of Environmental Concern on Environmentally Friendly Consumer Behavior: An Exploratory Study. J. Bus. Res. 1997, 40, 37-48. [CrossRef]

40. Stern, P.; Dietz, T.; Kalof, L. Value Orientations, Gender, and Environmental Concern. Environ. Behav. 1993, 25, 322-348. [CrossRef]

41. Grunert, S.; Juhl, H. Values, environmental attitudes, and buying of organic foods. J. Econ. Psychol. 1995, 16, 39-62. [CrossRef]

42. Ajzen, I.; Fishbein, M. Scaling and Testing Multiplicative Combinations in the Expectancy-Value Model of Attitudes. J. Appl. Soc. Psychol. 2008, 38, 2222-2247. [CrossRef]

43. Wandel, M.; Bugge, A. Environmental concern in consumer evaluation of food quality. Food Qual. Prefer. 1997, 8, 19-26. [CrossRef]

44. Chen, M.; Tung, P. Developing an extended Theory of Planned Behavior model to predict consumers' intention to visit green hotels. Int. J. Hosp. Manag. 2014, 36, 221-230. [CrossRef]

45. Cabuk, S.; Tanrikulu, C.; Gelibolu, L. Understanding organic food consumption: Attitude as a mediator. Int. J. Consum. Stud. 2014, 38, 337-345. [CrossRef]

46. Chen, M. Attitude toward organic foods among Taiwanese as related to health consciousness, environmental attitudes, and the mediating effects of a healthy lifestyle. Br. Food J. 2009, 111, 165-178. [CrossRef]

47. Chan, R.; Lau, L. Antecedents of green purchases: A survey in China. J. Consum. Mark. 2000, 17, 338-357. [CrossRef] 
48. Eze, U.; Ndubisi, N. Green Buyer Behavior: Evidence from Asia Consumers. J. Asian Afr. Stud. 2013, 48, 413-426. [CrossRef]

49. Smith, S.; Paladino, A. Eating clean and green? Investigating consumer motivations towards the purchase of organic food. Australas. Mark. J. 2010, 18, 93-104. [CrossRef]

50. Rivis, A.; Sheeran, P. Descriptive norms as an additional predictor in the theory of planned behaviour: A meta-analysis. Curr. Psychol. 2003, 22, 218-233. [CrossRef]

51. Ridha, R.N.; Wahyu, B.P. Entrepreneurship intention in agricultural sector of young generation in Indonesia. Asia Pac. J. Innov. Entrep. 2017, 11, 76-89. [CrossRef]

52. Shin, D. Towards an understanding of the consumer acceptance of mobile wallet. Comput. Hum. Behav. 2009, 25, 1343-1354. [CrossRef]

53. Brouwer, S.; Krol, B.; Reneman, M.; Bültmann, U.; Franche, R.; van der Klink, J.; Groothoff, J. Behavioral Determinants as Predictors of Return to Work After Long-Term Sickness Absence: An Application of the Theory of Planned Behavior. J. Occup. Rehabil. 2009, 19, 166-174. [CrossRef]

54. Vermeulen, J.; Neyens, J.; van Rossum, E.; Spreeuwenberg, M.; de Witte, L. Predicting ADL disability in community-dwelling elderly people using physical frailty indicators: A systematic review. BMC Geriatr. 2011, 11. [CrossRef]

55. Chen, F. Sensitivity of Goodness of Fit Indexes to Lack of Measurement Invariance. Struct. Equ. Model. Multidiscip. J. 2007, 14, 464-504. [CrossRef]

56. Galati, A.; Schifani, G.; Crescimanno, M.; Vrontis, D.; Migliore, G. Innovation strategies geared toward the circular economy: A case study of the organic olive-oil industry. Riv. Di Studi Sulla Sostenibilita. 2018, 8, 137-158. [CrossRef]

57. Wu, I.; Chen, J. Knowledge management driven firm performance: The roles of business process capabilities and organizational learning. J. Knowl. Manag. 2014, 18, 1141-1164. [CrossRef]

58. Han, H.; Hsu, L.; Sheu, C. Application of the Theory of Planned Behavior to green hotel choice: Testing the effect of environmental friendly activities. Tour. Manag. 2010, 31, 325-334. [CrossRef]

59. Fishbein, M.; Ajzen, I. Belief, Attitude, Intention, and Behavior: An Introduction to Theory and Research; Addison-Wesley Publishing Company: Boston, MA, USA, 1975.

60. Tan, G.; Ooi, K.; Sim, J.; Phusavat, K. Determinants of Mobile Learning Adoption: An Empirical Analysis. J. Comput. Inf. Syst. 2012, 52, 82-91.

61. Hernandez, M.C.J.; Afonso Mazzon, J. Adoption of internet banking: Proposition and implementation of an integrated methodology approach. Int. J. Bank Mark. 2007, 25, 72-88. [CrossRef]

62. Lin, S. Raising Public Awareness: The Role of the Household Sector in Mitigating Climate Change. Int. J. Environ. Res. Public Health 2015, 12, 13162-13178. [CrossRef]

63. Wang, J.; Chu, M.; Yuan Deng, Y.; Lam, H.; Tang, J. Determinants of pesticide application: An empirical analysis with theory of planned behaviour. China Agric. Econ. Rev. 2018, 10, 608-625. [CrossRef]

64. Ham, M.; Jeger, M.; Frajman Ivković, A. The role of subjective norms in forming the intention to purchase green food. Econ. Res.-Ekon. Istraživanja 2015, 28, 738-748. [CrossRef]

65. Zhang, D.; Huang, G.; Yin, X.; Gong, Q. Residents' Waste Separation Behaviors at the Source: Using SEM with the Theory of Planned Behavior in Guangzhou, China. Int. J. Environ. Res. Public Health 2015, 12, 9475-9491. [CrossRef]

66. Al Mamun, A.; Fazal, S.; Ahmad, G.; Yaacob, M.; Mohamad, M. Willingness to Pay for Environmentally Friendly Products among Low-Income Households along Coastal Peninsular Malaysia. Sustainability 2018, 10, 1316. [CrossRef]

67. Baker, E.; Al-Gahtani, S.; Hubona, G. The effects of gender and age on new technology implementation in a developing country. Inf. Technol. E People. 2007, 20, 352-375.

68. Laroche, M.; Bergeron, J.; Barbaro-Forleo, G. Targeting consumers who are willing to pay more for environmentally friendly products. J. Consum. Mark. 2001, 18, 503-520. [CrossRef]

69. Department of Statistics. Report of Household Income and Basic Amenities Survey 2016 (Online). Available online: https://www.dosm.gov.my/v1/index.php?r=column/cthemeByCat\&cat=120\&bul_id=RUZ5REwve U1ra1hGL21JWV1PRmU2Zz09\&menu_id=amVoWU54UT10a21NWmdhMjFMMWcyZz09\# (accessed on 5 September 2020).

70. Bryman, A. Quantitative and qualitative research: Further reflections on their integration. In Mixing Methods: Qualitative and Quantitative Research; Brannen, J., Ed.; Routledge: London, UK, 2017; pp. 57-78. 
71. Reinartz, W.; Haenlein, M.; Henseler, J. An Empirical Comparison of the Efficacy of Covariance-Based and Variance-Based SEM. Int. J. Res. Mark. 2009, 26, 332-344. [CrossRef]

72. Clark, D.; Douglas, H. Micro-enterprise growth: Lessons from homebased business in New Zealand. Small Enterp. Res. 2014, 21, 82-98. [CrossRef]

73. Park, E.; Ohm, J. Factors influencing the public intention to use renewable energy technologies in South Korea: Effects of the Fukushima nuclear accident. Energy Policy 2014, 65, 198-211. [CrossRef]

74. Dimov, D. Nascent Entrepreneurs and Venture Emergence: Opportunity Confidence, Human Capital, and Early Planning. J. Manag. Stud. 2010, 47, 1123-1153. [CrossRef]

75. Benzing, C.; Chu, H.; Kara, O. Entrepreneurs in Turkey: A Factor Analysis of Motivations, Success Factors, and Problems. J. Small Bus. Manag. 2009, 47, 58-91.

76. Liñán, F. Skill and value perceptions: How do they affect entrepreneurial intentions? Int. Entrep. Manag. J. 2008, 4, 257-272. [CrossRef]

77. Miralles, F.; Giones, F.; Riverola, C. Evaluating the impact of prior experience in entrepreneurial intention. Int. Entrep. Manag. J. 2015, 12, 791-813. [CrossRef]

78. Ha, H.; Janda, S. Predicting consumer intentions to purchase energy-efficient products. J. Consum. Mark. 2012, 29, 461-469. [CrossRef]

79. Podsakoff, P.; MacKenzie, S.; Lee, J.; Podsakoff, N. Common method biases in behavioral research: A critical review of the literature and recommended remedies. J. Appl. Psychol. 2003, 88, 879-903. [CrossRef]

80. Bagozzi, R.; Yi, Y.; Phillips, L. Assessing Construct Validity in Organizational Research. Adm. Sci. Q. 1991, 36, 421-458. [CrossRef]

81. Hair, J.; Ringle, C.; Sarstedt, M. PLS-SEM: Indeed a Silver Bullet. J. Mark. Theory Pract. 2011, 19, 139-152. [CrossRef]

82. Hair, J.; Ringle, C.; Sarstedt, M. Partial Least Squares Structural Equation Modeling: Rigorous Applications, Better Results and Higher Accepta. Long Range Plan. 2013, 46, 1-12.

83. Diamantopoulos, A.; Siguaw, J. Formative Versus Reflective Indicators in Organizational Measure Development: A Comparison and Empirical Illustration. Br. J. Manag. 2006, 17, 263-282. [CrossRef]

(C) 2020 by the authors. Licensee MDPI, Basel, Switzerland. This article is an open access article distributed under the terms and conditions of the Creative Commons Attribution (CC BY) license (http://creativecommons.org/licenses/by/4.0/). 